\title{
Terminologia työvälineenä - aikamuotojärjestelmästä ja sen opetuskäytänteiden ergonomiasta S2-opetuksessa
}

\author{
MARIA KOK \\ Itä-Suomen yliopisto
}

Tiivistelmä. Artikkeli käsittelee kahta ongelmalliseksi osoittautunutta verbien tempusnimitystä, perfektiö ja imperfektiä. Tarkastelen kirjoituksessani nimitysten välittämää informaatiota, jota vertaan S2-oppikirjoissa aikamuotojen käytöstä annettuun tietoon. Kriittisen katsauksen tavoitteena on osoittaa harhaanjohtavien termien haitta ja hyvän metakielen tarve sekä myös pohtia keinoja virheellisten nimitysten korjaamiseksi. Teoreettisena viitekehyksenä on työolosuhteita, työvälineitä ja työtapoja tutkiva ergonomia. Koska kielen opetus ja opiskelu ovat työtä ja metakieli on työväline, jolla opettaja ja opiskelijat yhdessä työskentelevät, on käytettävän termistön ammatillinen ja käytännönläheinen arviointi tarpeen.

Avainsanat: S2-opetus; imperfekti; perfekti; terminologia; aspekti; kognitiivinen ergonomia

\section{Johdanto}

Kun runsaat kaksi vuotta sitten otin vastaan kokoaikaiset S2-opettajan tehtävät, aikomukseni ei ollut ryhtyä tutkimaan suomen verbien aikamuotojärjestelmää. Tarkoitukseni oli yksinkertaisesti opettaa suomea mahdollisimman hyvin ja auttaa opiskelijoitani löytämään paikkansa 
suomalaisessa yhteiskunnassa. Aikamuodot olivat kuitenkin niin merkittävä osa ryhmieni opetusohjelmaa, etten yksinkertaisesti voinut olla huomaamatta niiden opetukseen liittyviä pulmia. Joutuessani ottamaan kantaa harhaanjohtavien tempusnimitysten ja puutteellisten kuvausten aiheuttamiin väärinkäsityksiin - toisinaan useita kertoja päivässä vakuutuin siitä, että opetuksen metakielessä olisi paljon parannettavaa. Siirryttyäni tutkijan töihin halusin omistaa osan ajastani opetustyössä kohtaamani problematiikan tarkempaan selvittelyyn ja S2-opetusalan kehittämiseen.

Jo pitkään on tiedetty, että suomen tempusjärjestelmää kuvaavassa termistössä on suuria puutteita, mutta asian korjaamiseksi ei ole ryhdytty käytännön toimiin. Laiminlyönnit kostautuvat nyt, kun hyvän termistön tarve olisi erityisen suuri. Suomea toisena kielenä opetetaan maassamme enemmän kuin koskaan aikaisemmin. Erityisen riippuvaisia hyvästä suomen kielen opetuksesta ovat ne pakolaisina Suomeen muuttaneet, jotka toivovat löytävänsä maastamme pysyvän kodin. Ilman kielitaitoa heidän mahdollisuutensa löytää töitä tai opiskelupaikka ovat heikot. Erityisesti heidän asemastaan olen huolissani.

Opettamiani ryhmiä ei valitettavasti enää ollut mahdollista jäljittää tutkimusluvan saamiseksi. Ryhmät olivat jo hajonneet ja opiskelijat siirtyneet työelämään tai toisiin oppilaitoksiin. Päätin siis opiskelijoiden, heidän tuotostensa ja virheidensä sijasta tarkastella niitä kognitiivisia välineitä, joilla opiskelijat ja opettajat joutuvat yhdessä työskentelemään. Erityisesti tarkastelen kahta menneen ajan verbikategoriaa, perfektiö ja imperfektiä, niiden kuvauksia S2-oppikirjoissa sekä niistä käytettävien nimitysten taustaa. Opiskelijoideni ajatuksiin ja kommentteihin joudun viittaamaan hyvin yleisellä tasolla, niin ettei yksittäistä opiskelijaa tai opetusryhmää voida tunnistaa.

Aineistonani on joukko yleisesti käytettyjä S2-oppikirjoja sekä kielioppeja eri aikakausilta. Tätä artikkelia varten olen valinnut lähemmin tarkasteltavaksi seuraavat teokset: 
- Hart, Susanna 2007. Suomea paremmin.

- Kangasniemi, Heikki 2007a. Suomen kielen tikapuut. Kielioppija harjoituskirja, Alkeistaso 1.

- Kangasniemi, Heikki 2007b. Suomen kielen tikapuut. Kielioppija harjoituskirja, Alkeistaso 2.

- Karanko, Marjatta, Ulla Paavilainen 2006. Tottakai! Suomen kielen alkeisoppikirja.

- Karlsson, Fred 2002. Finnish - An essential Grammar.

- Kenttälä, Marjukka 2006. Suomi sujuvaksi 1.

- Kuparinen, Kristiina, Terhi Tapaninen 2008. Hyvin menee! 2. Suomea aikuisille.

- Lepäsmaa, Anna-Liisa, Leena Silferberg 1998. Suomen kielen alkeisoppikirja.

- Tukia, Kaisa, Eija Aalto, Peppi Taalas, Sanna Mustonen 2004. Suomi 2 - Minä ja arki.

- White, Leila 2008. A Grammar Book of Finnish.

- White, Leila 2009. From Start to Finnish - a short course in Finnish.

Suurin osa teoksista on nimensä mukaan alkeisoppikirjoja, jotka kuitenkin edellyttävät käyttäjiltään lukutaitoa. Hieman edistyneemmille opiskelijoille suunnattuja oppikirjoja ovat "Suomea paremmin", jossa kerrataan suomen kielen perusteet, sekä "Hyvin menee 2". Peruskoulua käyville maahanmuuttajanuorille on suunnattu erityisesti "Suomi 2 Minä ja arki”. Muita kirjoja käyttävät enemmän aikuisopiskelijaryhmät. Leila Whiten "The Grammar Book of Finnish” on kielioppikäsikirja, samoin kuin Fred Karlssonin “The Essential Grammar”. Erityisesti Whiten kielioppi on suosittu itseopiskelun apuväline, samoin kuin hänen oppikirjansa "From Start to Finnish". Kaikissa valitsemissani kirjoissa käsitellään imperfektiä ja suurimmassa osassa myös perfektiä näitä perinteisiä nimityksiä käyttäen.

En puutu artikkelissani lukutaidottomien maahanmuuttajien enkä aivan nuorimpien peruskoululaisten S2-opetukseen. Heitä varten on 
olemassa omat menetelmänsä ja oppimateriaalinsa, joissa kielioppiterminologia ei ole keskeisellä sijalla. Rajoitun tarkastelemaan niiden opiskelijoiden tilannetta, joiden opetuksessa kielioppitermit normaalisti ovat mukana, ja pohdin keinoja heidän opiskelunsa edistämiseksi.

Vaikka imperfektin ja perfektin epäsopivuus suomen tempusnimityksinä tulee ilmeiseksi juuri S2-oppikirjoja tarkastelemalla ja vaikka asian korjaamisella juuri tässä käyttöyhteydessä olisi erityinen kiire, tarkoitukseni ei ole moittia oppikirjojen tekijöitä eikä heidän teoksiaan. Nimitykset ovat vakiintuneet kaikissa äidinkielen oppikirjoissa ja koko koulujärjestelmässämme. On selvää, että oppikirjojen tekijät haluavat sopeutua vakiintuneisiin käytäntöihin, varsinkin kun tarkoituksena on auttaa opiskelijoita integroitumaan suomalaiseen työ- ja koulumaailman. Kun lisäksi S2-opetusta toisinaan annetaan samassa ryhmässä kuin äidinkielenopetusta, on vain loogista käyttää yhteisiä nimityksiäkin. Myös aikamuotoja tutkineet asiantuntijat käyttävät kirjoituksissaan tavallisesti tuttuja, perinteisiä termejä (ks. mm. Wiik 1976). Oppikirjojen tekijöiltä ei voi odottaa, että he lähtisivät ensimmäisenä eri linjoille kuin ne, joita pidetään alan auktoriteetteina ja joiden näkemyksiin tukeudutaan.

Kielioppitermistön vaikutusta kielenoppimiseen on tutkinut aikaisemmin Kirsti Siitonen (1999), jonka mukaan opiskelijan oppimisprosessiin vaikuttavat hänen äidinkielensä lisäksi myös oman äidinkielen opetuksessa tutuksi tulleet kielioppitermit. Tuttu termi herättää opiskelijassa odotuksia ja oletuksia, jotka johtavat harhaan, mikäli äidinkielen ja opiskeltavan kielen termit eivät vastaa toisiaan (mts. 311). Siitonen on perehtynyt erityisesti ns. $U$-verbien oppimiseen ja opettamiseen. Näitä verbejä nimitetään perinteisesti refleksiiviverbeiksi, mutta merkitykseltään niistä on refleksiivisiä vain osa. Koska oppikirjat eivät tarjoa hyviä nimityksiä $U$-verbien eri merkitysryhmiä kuvaamaan, Siitonen on joutunut niitä itse kehittämään opetustyötään varten (mts. 84-91). $U$-verbien lisäksi hankalasti hahmotettavana kategoriana Siitonen mainitsee passiivin (mts. 93; ks. myös Tommola 1993). Verbien tempusten nimitykset eivät siis ole ainoa terminologista huoltoa kaipaava seikka. 
Kielioppiterminologiasta ongelmien lähteenä yleisemmin Siitonen (2003) on kirjoittanut "Lähivertailuja 12" -julkaisussa. Artikkelissaan hän ottaa kantaa myös tempusnimitysten harhaanjohtavuuteen. Siitonen pitää latinaan tai kreikkaan pohjautuvia kielioppitermejä vaarallisena virhelähteenä, kun ne lainataan sellaisenaan kieleen, joka on rakenteeltaan aivan erilainen. Hänen mielestä on tärkeää, että opiskelijat tuntevat ne perinteiset termit, joita suomen kuvauksessa käytetään. Näin alan kirjallisuus pysyy opiskelijoille ymmärrettävänä. Uusien termien luomista Siitonen pitää kuitenkin toivottavana (mts. 81-85). Artikkelin kirjoittamishetkellä "Iso suomen kielioppi” oli työn alla, ja monet - Siitonen mukaan lukien (mts. 84) - odottivat, että ongelmallisia termejä siinä korjattaisiin. Teoksessa saatiinkin aikaan mittavia parannuksia, ja myös ongelmalliset tempusnimitykset oli tarkoitus uudistaa. Kentältä tullut - ilmeisesti äidinkielenopettajien antama - palaute kuitenkin aiheutti sen, että tästä muutoksesta luovuttiin (Irja Alhon (29.08.2011) ja Maria Vilkunan (02.02.2012) sähköpostiviestit). Tuolloin ei ehkä vielä osattu ennakoida lisääntyvän S2-opetuksen tarpeita. Yksi tilaisuus korjata pitkään tiedossa ollut ongelma meni sivu suun.

Edellytykset kielioppitermien tutkimukseen, päivitykseen ja huoltoon ovat tällä hetkellä ehkä paremmat kuin koskaan. Suomen akatemian rahoittama 5-vuotinen Tieteen kansallinen termipankki -hanke on aloittanut mittavan tieteellisten termien kartoitustyön, ja yhtenä sen kolmesta pilottihankkeesta on kielitieteen terminologia. Kielitieteen osalta hanketta johtaa Helsingin yliopiston suomen ja suomalais-ugrilaisten kielten laitos. Hankkeen yhteistyökumppaneina toimivat mm. Kotimaisten kielten keskus sekä Sanastokeskus TSK. Kielitieteen pilotin osalta hanke toteutetaan talkootyönä, johon kielen asiantuntijoiden myös S2-opettajien - toivotaan osallistuvan runsain joukoin. Hankkeen kaikille avoimilta kotisivuilta (ks. TKTP kirjallisuusluettelossa) työn etenemistä voi seurata reaaliajassa. Sivustolta löytyy myös tietoa mahdollisuuksista osallistua termityöhön käytännössä.

Suomen tempusjärjestelmä on hieno ja joustava systeemi, joka mahdollistaa kompleksisten aikasuhteiden vivahteikkaan hahmottamisen ja 
kuvaamisen. Sen omaksuminen vaatii työtä mutta myös palkitsee vaivan. Alkeis- ja perustason opiskelijoille aikamuotoihin tutustuminen on tärkeä välitavoite. Heidän itsenäisyytensä kielenkäyttäjinä lisääntyy, kun aikamuotojen myötä heille avautuu pääsy kertomuksiin ja muihin kiinnostaviin tekstilajeihin. Pidemmällä olevat opiskelijat puolestaan toivovat neuvoja tempusten keskinäisestä työnjaosta ja oikean aikamuodon valitsemisesta. Niillä edistyneemmille opiskelijoille tarkoitetuilla lyhyt- ja teemakursseilla, joita olen saanut pitää, aikamuotojärjestelmä on jatkuvasti ollut suosittu aihe. Sen syvällisempää käsittelyä opiskelijat erityisesti pyytävät. Hienot oppimistavoitteet ja motivoituneet opiskelijat ansaitsevat työskentelyynsä parhaat mahdolliset välineet.

\section{Termit työkaluina}

Koska tarkoituksenani on tutkia verbien aikamuotoja osana S2-opiskelijan ja -opettajan arkista työskentelyä, lähestyn aikamuotojen problematiikkaa ergonomian näkökulmasta. Ergonomia on oppi työstä, työmenetelmistä ja työvälineistä. Se on poikkitieteellinen tutkimussuuntaus, joka pyrkii parantamaan työolosuhteita ja työn tuloksia sovittamalla työvälineistön tekijälleen sopivaksi. Ergonomia yliopistollisena oppiaineena voi kuulua esimerkiksi lääke- ja terveystieteen opintokokonaisuuksiin. Arkipäivän työelämässä ergonomia taas on ratkaisukeskeinen lähestymistapa, jolla pyritään välittömiin käytännön parannuksiin. Lähes kaikilla ammattialoilla on oma ergonominen tietotaitonsa, jota myös opetetaan alan koulutuksissa. Suomessa eri ammattialojen ergonomiaa tutkii ja siitä tiedottaa Työterveyslaitos. Sellaista tutkimussuuntausta kuin kieliopillinen ergonomia ei käsittääkseni vielä ole. Jos kielen opettaminen ja opiskeleminen katsotaan työksi, alalle olisi hyvä luoda oma ergonominen tietotaito. Sen avulla voitaisiin tarkastella kriittisesti ja ratkaisukeskeisesti niitä keinoja ja välineitä, joita työssä käytetään.

Kotisivuillaan (ks. TTL kirjallisuusluettelossa) Työterveyslaitos esittelee ergonomian eri lajeina fyysisen, organisatorisen ja kognitiivisen ergonomian. Fyysinen ergonomia tutkii konkreettisia työvälineitä, 
työtiloja, työotteita ja työmenetelmiä sekä pyrkii parantamaan niiden turvallisuutta, tarkoituksenmukaisuutta ja käyttömukavuutta. Organisatorisen ergonomian tarkoituksena taas on sovittaa yhteen työpaikan tekninen ja sosiaalinen järjestelmä parantamalla työyhteisöjen järjestystä, työnjakoa ja työaikataulua. Kognitiivinen ergonomia liittyy TTL:n mukaan erilaisiin tietoympäristöihin, ja siinä pyritään tiedon esittämiseen ja järjestämiseen sellaisella tavalla, että se sopii yhteen ihmisen havaitsemisen, muistin ja muiden kognitiivisten kykyjen kanssa. Opettajan työssä kaikki ergonomian lajit ovat relevantteja, mutta uskoisin erityisesti kognitiivisesta ergonomian olevan apua, kun halutaan arvioida ja kehittää kielenopetuksen metodiikkaa. Ovathan sekä oppiminen että opettaminen kognitiivisia prosesseja, ja onhan opettaminen hyvin pitkälle nimenomaan juuri tiedon esittämistä.

Mitä sitten olisivat opetusalan kognitiiviset työvälineet? Kirjojen, äänitteiden ja tietotekniikan lisäksi käytämme jatkuvasti apuneuvoja, joita emme heti miellä työkaluiksi, koska ne eivät ole fyysisiä objekteja. Voidaksemme puhua kielestä ja tehdä näkyväksi siihen liittyvää tietoa, tarvitsemme kuitenkin metakielen. Siihen kuuluvat olennaisena osana kieliopilliset luokitukset ja käsitejärjestelmät, joiden kielellisiä ilmiasuja ovat termit. Lisäksi tarvitaan määritelmiä, selityksiä ja selitysmalleja, harjoitusmateriaalia ja esimerkkejä sekä havainnollistavaa välineistöä. Näiden kaikkien tarkoituksenmukaisuutta voidaan arvioida ergonomian näkökulmasta. Koska tämä välineistö on luonteeltaan pitkälti kielellistä, resursseja sen kehittämiseksi kannattaisi lisäksi etsiä terminologian ja sanaston tutkimuksen piiristä. "Sanastotyön oppaassa" (Haarala 1981: 11) erikoisalojen kieltä verrataankin työkaluun. Siihen kohdistuu suurempia täsmällisyyden, loogisuuden ja selkeyden vaatimuksia kuin päivittäiseen kieleen, ja se tarvitsee myös huoltoa aika ajoin. Erikoisalojen ammattikieltä ja -termistöä tutkii, kehittää ja huoltaa maassamme Sanastokeskus TSK ry. Järjestö pitää yllä eri ammatti- ja tieteenalojen termipankkeja ja antaa neuvontaa ammatillisessa sanastotyössä. Sanastokeskuksen “TEPA-termipankista” löytyy tällä hetkellä yhteensä 69 erityisalan omaa sanastoa. Kielitieteen tai kielenopetuksen 
termistöä ei tästä joukosta vielä löydy, mutta parhaillaan sitä kokoaa Tieteen termipankki -hanke. Sanastokeskuksen julkaisut ja verkkosivusto (ks. SK-TSK kirjallisuusluettelossa) tarjoavat paljon resursseja ja asiantuntemusta termityöhön.

\section{Tempusnimitysten lyhyt muodollinen analyysi}

Termillä tarkoitetaan Sanastokeskuksen “Terminologiasanaston” (TSK 36: 22) mukaan "erikoisalalla käytettävää yleiskäsitteen nimitystä”. Se on täsmällisesti määritellyn käsitteen kielellinen nimitys, joka on omalla erikoisalallaan yleisesti tunnettu, hyväksytty ja vakiintunut (Haarala 1981: 16). Termejä voidaan analysoida ja luokitella esimerkiksi rakenteen mukaan ja tutkia, onko kyseessä yhdestä juurimorfeemista muodostunut termi, johdostermi, yhdyssana vai sanaliitto. Alkuperän mukaan tarkasteltaessa kiinnitetään huomiota siihen, onko termi omaperäinen vai lainattu joko jostain toisesta kielestä tai joltain toiselta erikoisalalta. (TSK 63: 22-25.) Tarkasteltavina voivat olla myös eri käsitteiden väliset suhteet eli se, millaisen järjestelmän ne keskenään muodostavat (TSK 63: 27-29; Haarala 1981: 22-32). Lisäksi termi voidaan arvioida suositeltavaksi, sallittavaksi tai hylättäväksi (TSK 63: 22-25). Tarkastelenkin aluksi näitä lähtökohtia hyödyntäen, miten suomen menneen ajan tempusten nimitykset on rakennettu ja millaista tietoa niihin on koodattu.

Suomen tempusjärjestelmän kolmea menneen ajan muotoa nimitetään perinteisesti imperfektiksi, perfektiksi ja pluskvamperfektiksi. Kaikki nämä ovat yhdysmuotoisia lainatermejä, jotka on kyllä luotu kuvaamaan kieltä, mutta toisenlaista kuin omamme, tarkemmin sanoen latinaa. Yhdessä nimitykset näyttäisivät ensi näkemältä muodostavan kolmiosaisen järjestelmän, jonka jokainen jäsen sisältää yhteisen osan perfekti (perfectum = lat. 'loppuun saatettu, täydellinen'). Rakenteen ja keskinäisten suhteiden mukaan tarkasteltuna perfektin voi ajatella käsiteryhmän ydinjäseneksi, josta muut on johdettu. Perinteisiin nimityksiin tottuneet harvemmin ajattelevat imperfektiä yhdyssanamuodoksi, ja suomalaiset ääntävätkin sanan pääpaino sen ensimmäisellä tavulla ja 
geminaatta-p:llä: “impperfekti”. Sana sisältää kuitenkin selvästi etuliitteen im-, 'ei', 'epä-', ja sen suhde perfekti-termiin on siis antonyyminen, 'ei-perfekti', 'ei loppuun saatettu', 'keskeneräinen', 'jatkuva'. Nimitys pluskvamperfekti puolestaan viittaa perfektiivisyyden suurempaan määrään tai korkeampaan asteeseen ( $p l u s=$ lat. 'lisää, enemmän'; quam = 'kuin'). Pelkän termistön perusteella voisimme siis päätellä, että suomen verbeillä on jonkinlainen täydellisyyttä tai lopullisuutta ilmaiseva taivutusmuoto perfekti, sen vastakohta im-perfekti ja korkeampi aste pluskvam-perfekti. Nimityksistä itsestään ei kuitenkaan voi nähdä, että ne ovat menneen ajan tempusten nimityksiä, sillä mikään niissä ei viittaa toiminnan tai tapahtuman ajankohtaan.

Termit imperfekti, perfekti ja pluskvamperfekti ovatkin itse asiassa sanaliittotermin (TSK 36: 26) määritteenä toimivia jälkiosia, ja sanaliiton pääsana preteriti tai praeteritum, 'mennyt aika', on jäänyt käytöstä pois, ilmeisesti mukavuussyistä. Termien täydelliset latinankieliset asut olisivat praeteritum imperfectum, praeteritum perfectum ja praeteritum plusquamperfectum. Tämänkaltaisissa asuissa termit tavataankin suomen vanhimmissa kieliopeissa (Petraeus 1649: 26-37; Martinius 1689: 48-61; Vhael 1733: 88-101). Niillä ei tosin viitattu täsmälleen samoihin verbikategorioihin kuin nykyisissä oppikirjoissa (ks. myös Vihonen 1979: 123). Nykyiset tempusnimitykset ovat siis oikeastaan lyhenteitä (TSK 36: 22) eli nimityksiä, jotka on "muodostettu jättämällä sanoja tai kirjaimia pois pidemmästä, samaan käsitteeseen viittaavasta nimityksestä”. Poisjäänyt pääsana edustaa yläkäsitteen tasoa, ja juuri siitä ilmenee, että termit on tarkoitettu tempusten nimitykseksi. Käyttöön jääneet määritteet täsmentävät, millaisesta menneisyyteen sijoittuvasta toiminnasta on kyse: keskeneräisestä tai jatkuvasta (imperfekti), loppuunsaatetusta (perfekti) vai aikaisemmin loppuun saatetusta (pluskvamperfekti). Käyttämämme tempusnimitykset ovat siis itse asiassa aspektien (ISK \$ 1498) nimityksiä ja viittaavat toiminnan tai tapahtuman sisäiseen aikarakenteeseen eivätkä niinkään tapahtuma-ajankohtaan.

Sanastokeskus ei anna virallista arviota tempustermien suositeltavuudesta, koska sillä ei ole vielä omaa kielitieteen sanastoa. Ruotsin 
Rikstermbanken suosittelee kuitenkin preteritum-nimitystä sille yksinkertaiselle menneen ajan muodolle, joka vastaa suomen imperfektiksi kutsuttua muotoa. Termi imperfekt luokitellaan sallittavaksi (engl. admitted) termiksi:

(1) I stället för preteritum används ibland termen imperfekt. (http://www. rikstermbanken.se/rtb/visaTermpost.html?id=99758 (20.06.2012))

Vaikka termit imperfekti, perfekti ja pluskvamperfekti ovat suomen kieliopillisissa kuvauksissa vakiintuneet, on merkillepantavaa, että kukaan ei näy niitä erityisesti suosittelevan. Varsinkin imperfektiä on kritisoitu:

(2) Tämä vakiintunut kieliop. nimitys on oikeastaan asiallisesti harhaanjohtava (lat. imperfectum 'päättymätön' - tekemisen päättymättömyys eli jatkuvuushan ei ole "imperfektillemme" luonteenomaista, kuten se on latinan vastaavanimiselle tempukselle. Parempi nimitys olisi preteriti ('menneisyys, menneen ajan tempus'). (Hakulinen 1979: 247-248, alaviitteessä.)

(3) Preteriti ilmaisee ennen puhumishetkeä tapahtunutta, aspektin suhteen neutraalia tekemistä. Suomen ja lapin ${ }^{\star} j$-suffiksillinen ns. imperfekti (esim. kantoi $=$ lp. gū ddii) on luonteeltaan preteriti, sillä se ei suinkaan merkitse merkitse yksinomaan menneeseen aikaan kuuluvaa päättymätöntä tekemistä, johon sen nimi (< lat. imperfectum) viittaa. (Itkonen 1966: 281.)

Tällaiset kannanotot ovat yleensä varovaisia, ja esimerkiksi Hakulinen tyytyy käyttämään imperfekti-termiä kriittisen arvionsa jälkeenkin. Itkosta ja Hakulista pidetään kuitenkin arvovaltaisina asiantuntijoina. Heidän maltillisenkin kritiikkinsä voisi katsoa perusteeksi sille, ettei ainakaan imperfektiä voitaisi suositella. Termejä perfekti ja pluskvamperfekti on arvioitu suositeltavuuden kannalta toistaiseksi hyvin vähän. 


\section{Menneen ajan tempukset S2-oppikirjoissa}

Kun tempusnimitysten kantamaa informaatiota verrataan siihen tietoon, jota esitetään tempusten todellisesta käytöstä, on aivan ilmeistä, että jokin ei täsmää. Alla olevat esimerkit ovat lainauksia S2-oppikirjoista. Olen lihavoinut kohdat, joista on nähtävissä termin ja sen tarkoitteen välinen ristiriita.

\section{Imperfektin kuvauksia:}

(4) The imperfect tense tells us what happened before the moment of utterance, at a certain point of time in the past. The event or state of affairs is all over, finished. The moment of past action or event is specified. (White 2008: 199.)

(5) Imperfekti: mennyt aika; usein tarkka aika. (Hart 2007: 10.)

(6) Imperfekti - tekeminen on loppunut

Asuin Espanjassa vuosina 2000-2002.

Pentti työskenteli metallialalla vuoteen 2003 saakka. (Kuparinen \& Tapaninen 2008: 53.)

\section{Perfektin kuvauksia:}

(7) Something has happened some time in the past, but the exact time is not given. ---

What is happening started some time before, but is still relevant at the moment of utterance. What has been is still going on, and is still there.

Something has not happened until the moment of utterance, but could happen later. There still is a chance ---. (White 2008: 200-201.)

(8) Perfekti: mennyt aika; ei tarkkaa aikaa tai on jatkunut tähän asti. (Hart 2007: 10.)

(9) Perfekti - tekeminen jatkuu

Olen asunut Suomessa kaksi vuotta.

Matti on työskennellyt viisi vuotta. (Kuparinen \& Tapaninen 2008: 53.) 
Samantapaisia kuvauksia esittävät myös Kangasniemi (2007b: 90), Kenttälä (2007: 229-30) sekä Tukia, Aalto, Taalas ja Mustonen (2004: 84-85, 197): Imperfektiksi nimitettyyn verbimuotoon liitetään perfektiivisiä ja määräisiä ominaisuuksia, kuten tapahtumien kokonaan menneisyyteen sijoittuminen, toiminnan loppuun saattaminen ja tapahtuma-ajankohdan tarkka ilmoittaminen. Perfektiksi nimitettyyn aikamuotoon taas liitetään imperfektiivisiä ja epämääräisiä ominaisuuksia, kuten puhehetkellä vielä jatkuva toiminta ja epämääräinen tapahtuma-ajankohta.

Tämäntapaiset aikamuotojen luonnehdinnat eivät rajoitu S2-oppimateriaaliin. Seuraavat poiminnat ovat "Kielikellosta" (3/2011; 1/1997). Riitta Korhonen antaa artikkelissaan vastauksia suomalaisten usein esittämiin kysymyksiin sopivan aikamuodon valinnasta. Erkki Lyytikäisen kirjoitus taas käsittelee tempusten perus- ja erikoiskäyttöä. Koska lihavoinnit olivat tekstissä alkuperäisiä, olen nyt kursivoinut kohdat, jotka viittaavat termin ja sen tarkoitteen ristiriitaan.

(10) Imperfekti on menneen ajan kerronnan aikamuoto. Tilanne esitetään päättyneenä. Se ikään kuin kiinnittyy menneeseen aikaan, mahdollisesti osana tapahtumien ketjua.

--- perfekti ilmaisee yhteydestä riippuen toisaalta aiemmin alkanutta ja yhä jatkuvaa ja toisaalta mennyttä tilannetta, jolla on tavalla tai toisella vaikutusta nykyhetken kannalta. (Korhonen 2011: 6.)

(11) Kun kerran perfektin ilmoittaman tekemisen ajankohtaa ei tarkasti tiedetä, perfektin käyttö antaa kuvaamastaan asiasta hiukan epämääräisen vaikutelman.

Perfektiin verrattuna imperfekti antaa asiasta luotettavamman kuvan. Koska kertoja tietää tapahtumisen ajankohdan, hän on ehkä suorastaan nähnyt koko tapahtuman ja on ikään kuin luotettavampi todistaja. (Lyytikäinen 1997: 9-10.)

Kaikkia edellä esitettyjä luonnehdintoja voidaan sinänsä pitää oikeina ja esimerkkejä osuvina. Ne antavat hyvän käsityksen eri tempusten tyypillisestä käytöstä ja niiden välisistä merkityseroista. Verbikategorioille annetut nimitykset sen sijaan näyttäisivät suorastaan vaihtuneen keskenään. (Ks. myös Siitonen 2003: 85.) 
Kun kerran imperfektiksi kutsuttu verbimuoto on käytännössä usein perfektiivinen, voisiko sitä myös alkaa kutsua perfektiksi? Jos termit perfekti ja imperfekti ovat epähuomiossa vaihtuneet, eikö olisi yksinkertaisinta vaihtaa ne takaisin? Ajatus voi vaikuttaa aluksi houkuttelevalta: nurinkurinen tilanne korjaantuisi ilman, että tutuiksi käyneistä nimityksistä tarvitsisi luopua. Termien ja niiden tarkoitteiden vastaavuus näyttäisi myös todella paranevan jonkin verran. Mikään kestävä ratkaisu vaihdos ei kuitenkaan olisi, sillä perfekti voi toisinaan todella olla perfektiivinen ja imperfekti imperfektiivinen. Lisäksi termit sisältäisivät edelleen oletuksen aikamuotojen välillä vallitsevasta aspektuaalisesta oppositiosta, jollaista ei kuitenkaan automaattisesti ole.

Perfektiksi kutsutun aikamuodon kuvauksissa mainitaan usein, että se kuvaa sellaista toimintaa, joka on nykyhetken kannalta jollain tavoin relevanttia (ks. esim. Karlsson 1982: 154; Kangasniemi 2007b: 90; White 2008: 200). Tällainen toiminta ei kuitenkaan aina ole keskeneräistä tai jatkuvaa. Whiten (2008) esimerkkejä nykyhetken kannalta relevantista mutta kuitenkin päättyneestä tapahtumasta - ja siis perfektiivisestä ovat esimerkiksi elossa olevan henkilön syntymä ja olemassa olevan talon rakennusvuosi:

(12) Roope on syntynyt vuonna 1977.

Tämä talo on rakennettu vuonna 1897. (White 2008: 200.)

Päättyneitä ovat myös luonteeltaan sellaiset tapahtumat, joita puhuja ei ole nähnyt mutta joista on jäänyt havaittavia jälkiä:

(13) Viime yönä on satanut lunta. (Näen, että maa on valkoinen.)

- Eilen on ollut kova myrsky. (Näen, että monta puuta on kaatunut.)

- Hyi, mikä haju! Täällä on poltettu tupakkaa. (White 2008: 201.)

Merkitykseltään imperfektiivisen imperfektin havainnollistamiseksi opettajan omat esimerkit ja autenttiset tekstit ovat usein tarpeen, sillä siitä ei ole oppikirjoista helppoa löytää hyviä esimerkkejä. Kirjoissa tempusten merkityseroja esitellään yleensä lyhyiden lauseiden tai lauseparien avulla. Niissä imperfektiksi kutsutun muodon aspekti on pääsääntöisesti 
perfektiivinen, koska pyrkimyksenä on nimenomaan osoittaa asian olevan näin. Kertovassa tekstissä kuitenkin esimerkiksi sääolosuhteet ja erilainen taustatoiminta voivat olla aspektiltaan avoimia. Nehän voivat jäädä jatkumaan varsinaisten juonitapahtumien edetessä. Seuraava kertomuskatkelma löytyi oppikirjasta “Tottakai!":

(14) Ilta oli hauska. Aikuiset pelasivat korttipelejä ja kuuntelivat musiikkia Jonnan huoneessa. Jussi leikki pienten lasten kanssa piilosta. - Minä näen sinut, huusi Lauri Jussille. - Sinä löydät minut aina heti, Jussi valitti. (Karanko \& Paavilainen: 142.)

Esimerkissä korttipelien pelaaminen, musiikin kuuntelu ja piiloleikki ovat taustatoimintaa, joka voidaan tulkita imperfektiiviseksi. Kielissä, joissa on aspektitaivutus, niitä ilmaistaisiin eri verbimuodoilla kuin huutamista ja valittamista, jotka kuljettavat kertomusta eteenpäin. Suomessa kertomuksen taustatoimintaa ja juonitapahtumia ilmaisemaan käy sama tempus.

Suomessa aikamuodon vaihtaminen toiseksi ei kaikissa tapauksissa edes muuta aspektia. Seuraavissa lausepareissa verbin ilmaisema toiminta on yhtä rajattua ja päättynyttä kummassakin aikamuodossa:

(15) Hei, oletko kuullut, että Liisa on ostanut uuden auton?

Hän osti sen viime viikolla.

Roope on syntynyt vuonna 1977.

Minä vuonna Shakespeare syntyi? (White 2008: 200.)

On paljon tilanteita ja monia verbejä, joiden kohdalla perfektin ja imperfektin välinen aspektuaalinen ero on minimaalinen. Vaihtamalla aikamuotojen nimityksiä keskenään saavutettaisiin ehkä jonkinasteinen kvantitatiivinen hyöty: virheellisyyden määrä vähenisi jonkin verran. Termit jäisivät silti edelleen ontuviksi. Vähemmän virheellinen ei ole vielä sama kuin hyvä. 


\section{Onko termeillä väliä?}

Mitä haittaa ontuvista termeistä sitten on? Eikö ole pääasia, että opiskelijat osaavat muodostaa tarvittavat muodot ja käyttää niitä? Eikö kielioppitermi ole loppujen lopuksi vain latinankielinen sana, jonka sisältöä kukaan ei kuitenkaan jää miettimään? Tällainen ajatustapa on peräisin äidinkielen opetusperinteestä, jossa kielioppitermien rooli on käytännössä onomastinen: termit ovat äänneyhdistelmiä, jotka opetellaan muistamaan ja yhdistämään tiettyyn kielenyksikköön tai kategoriaan. Niitä ei juurikaan analysoida tai selitetä, koska pidetään samantekevänä, ymmärtääkö opiskelija äänneyhdistelmän merkityksen ja onko termi sisällöllisesti oikea. Kovin suurta vahinkoa ei näin ehkä saadakaan aikaiseksi, sillä suomalainen lapsi on oppinut tärkeimpien kieliopillisten kategorioiden muodostuksen ja käytön jo ennen kouluun tuloaan. Hän tarvitsee metakieltä voidakseen puhua kielestä, mutta ei oppiakseen puhumaan. Huonosti valitut termit voivat kyllä vahingoittaa hänen opiskelumotivaatiotaan mutta eivät hänen kielitaitoaan. Jos oppilas huomaa ristiriitaisuuksia termien ja niiden tarkoitteiden välillä, hänen arvostuksensa äidinkielen opetusta kohtaan kärsii kenties kolhun mutta tuskin hänen viestintätaitonsa.

Suomea vieraana kielenä opiskelevalla tilanne on aivan toinen. S2-opiskelija tukeutuu termeihin, koska olettaa aivan oikeutetusti niiden sisältävän tietoa siitä kielen yksiköstä, johon ne liitetään. Lainoina monet kielioppitermit saattavat kuulua niihin harvoihin sanoihin, joissa on jotain tuttua. Sisällöllisesti epäonnistuneet nimitykset voivat pettää opiskelijan, jolla omista lähtökohdistaan käsin ei ole mitään mahdollisuutta päätellä ennakolta, mitkä termit ovat luotettavia ja mitkä eivät. Eniten aikamuotojemme nimitysten ajatellaan usein haittaavan sellaisia opiskelijoita, joiden äidinkielessä on verbien aspektitaivutus. Hämmennys voi kuitenkin olla vielä suurempi niillä opiskelijoilla, jotka auttavilla englannintaidoillaan tietävät, mitä perfect ja imperfect arkipäivän sanoina merkitsevät, mutta joiden äidinkielessä ei esiinny sellaisia tempuksen ja aspektin yhdistelmiä kuin vaikkapa ranskassa. He eivät pelkkien termien 
avulla välttämättä edes pysty päättelemään, että perfekti ja imperfekti ovat aikamuotoja. Omaan opetusryhmääni on toisinaan tullut opiskelijoita, jotka osasivat muodostaa ns. imperfektin, mutta eivät tienneet sen olevan menneen ajan tempus. Tällainen on onneksi harvinaista, mutta näin voi käydä, mikäli opiskelijan käyttämässä kirjassa tämä aikamuoto on esitelty ilmoitusluontoisesti (esim. Kangasniemi 2007a: 167-169; Lepäsmaa \& Silferberg 1998: 115-119) ja opettaja on ilman muuta olettanut kaikkien ymmärtävän, mitä nimitys imperfekti merkitsee.

Riippumatta opiskelijan äidinkielestä S2-opettaja joutuu käyttämään aikaa imperfekti- ja perfekti-nimitysten selittämiseen ja purkamiseen. Niille, joiden tuntevat sanat, on selvitettävä, etteivät ne suomen kieliopissa tarkoita samaa kuin arkipuheessa tai toisten kielten kieliopeissa. Myös niille, joille nimitykset eivät ole tuttuja, asia on selitettävä, vaikka aikamuodoille voidaan tällöin keksiä hyvät tilapäisnimityksetkin. Koska lähes jokaisessa oppikirjassa yhtä kaikki käytetään käsitteitä imperfekti ja perfekti, niiden olemassaoloa ei voi opiskelijoilta salata, varsinkin kun niiden merkitys usein halutaan tietää. Opettaja ei myöskään voi pitää samaa opetusryhmää itsellään kovin pitkään. Opiskelijat siirtyvät aikanaan toisiin kouluihin, joissa harhaanjohtaviin termeihin tutustuminen on joka tapauksessa edessä. Opiskelijoita ei voi jättää väärinkäsitysten valtaan, mutta virheellisiltä nimityksiltä suojeleminenkaan ei ole hyväksi. Nykytilanteessa on opiskelijan kannalta ilman muuta paras, että hän tuntee perinteiset nimitykset mutta on myös tietoinen niiden ongelmallisuudesta, mikä teettää tietenkin ylimääräistä työtä ja voi luonnollisesti saada opettajat tai oppikirjat vaikuttamaan opiskelijan silmissä vähemmän asiantuntevilta.

Valitettavan usein S2-opettaja ei kuitenkaan ole perillä termien ja niiden tarkoitteiden välisestä ristiriidasta. Ulkomaisissa yliopistoissa suomea opiskelevat opiskelijat, joita olen kesäkursseilla opettanut, ovat kyllä tavallisesti tienneet, että imperfekti ja perfekti ovat epäonnistuneita nimityksiä suomen tempuksille. Heidän opettajansa ovat kokeneita, korkeasti koulutettuja asiantuntijoita, jotka ovat olleet ongelmasta tietoisia. Monille suomalaisille suomen pääaineopiskelijoille - tuleville S2-opetta- 
jille - sen sijaan on ollut yllättävää kuulla, että suomen tempusnimitykset ovat ongelmallisia. Siitosen (2003: 83) mukaan opettajan velvollisuus on olla tietoinen paitsi opiskelijoidensa äidinkielen piirteistä myös heidän kielessään käytettävästä terminologiasta. Vain näin hän pystyy auttamaan opiskelijoita irti "terminologisista kahleista" (Siitonen 1999: 311) ja hahmottamaan, mikä opiskelijoille tuottaa vaikeuksia. Lisäisin tähän, että aivan välttämätöntä opettajan olisi tuntea perin pohjin oman kielensä terminologia. Tämä ei ole mikään itsestäänselvyys. Äidinkielenopetuksessa ei ole tavallista, että kielioppitermien merkityksiä analysoitaisiin, eikä yliopistokursseillakaan asiaan kiinnitetä aina riittävästi huomiota. Vastavalmistunut S2-opettaja voi hyvinkin saada ensimmäisen työpaikkansa ennen kuin on koskaan ehtinyt miettiä käyttämiensä termien sisältöä.

\section{Kompastuskivistä rakennuskiviksi}

Sinänsä perfekti ja imperfekti voisivat olla aivan hyödyllisiä termejä. $\mathrm{Ne}$ ovat peräisin latinan kielen kuvausjärjestelmästä ja sopivat siihen mainiosti, koska latinan aikamuodot ovat luonteeltaan tempuksen ja aspektin yhdistelmiä. Vaikka suomessa verbeillä ei ole varsinaista aspektitaivutusta, aspekti sinänsä on kuitenkin suomen kielessä relevantti ilmiö, erityisesti lausesemanttisella tasolla. Tärkeitä aspektin ilmaisun keinoja ovat mm. objektin sijan valinta. Partitiiviobjektilla on taipumus liittää verbin toimintaan avoin, rajaamaton aspekti, kun taas totaaliobjekti esittää toiminnan loppuun saatettuna. (ISK \ 1498.) Lisäksi useilla verbijohdoksilla (ISK $\$ 1499$ ) ja moniosaisilla predikaateilla (ISK $\S 452$ ) on aspektuaalinen luonne. Verbiparit hypähtää ja hyppelehtiä ovat sisäiseltä aikarakenteeltaan erilaisia, samaten verbit istahtaa ja istuskella tai vetäistä ja vetelehtiä. Verbiparien ensimmäisen jäsenen ymmärrämme ilmaisevan punktuaalista, rajattua tai resultatiivista toimintaa, kun taas jälkimmäinen ilmaisee jatkuvaa ja aikarakenteeltaan avoimempaa toimintaa. Myös johtamattomilla perusverbeillä on oma sisäinen aspektinsa. Sellaiset verbit kuin kuolla tai tappaa ilmaisevat luonnostaan 
erilaista toimintaa kuin vaikkapa verbit pelätä, inhota ja hävetä. "Isossa suomen kieliopissa” ( $\$ 1508)$ puhutaankin rajapakoisista, rajaavista ja rajahakuisista verbeistä. Ilmaisun lopullinen aspekti on viime kädessä monen asian summa, ja myös verbin aikamuodon valinta voi siihen vaikuttaa, ei kuitenkaan aina eikä kaikilla verbeillä samalla tavoin.

Suomen aspekti on monitahoinen lausesemanttinen ilmiö, mutta siihenkin liittyvät asiat ovat S2-opetuksessa tarpeellisia. Samat opiskelijat, jotka toivovat aikamuotojen kertausta, haluavat usein myös syventää tietojaan objektin sijavalinnasta. Verbisanaston laajentaminen ja aspektuaalisiin verbijohdoksiin tutustuminen olisivat heille niin ikään tarpeen. Hyvää käsitejärjestelmää ja termistöä tämän mutkikkaan kokonaisuuden selventämiseksi kaivattaisiin, ja juuri tässä nimitykset perfekti ja imperfekti voisivat olla sopivat. Niitä ei kuitenkaan voi hyödyntää aspektin kuvauksessa niin kauan kuin niitä käytetään tempusnimityksinä. Kielentutkija on harjaantunut hahmottamaan, milloin puhutaan perfektistä ja imperfektistä tempuksena ja milloin aspektina, jopa jos käsitteet esiintyvät samassa tekstissä rinnakkain (esim. Kangasmaa-Minn 1993). S2-opiskelijoista tähän kykenevät vain edistyneimmät.

\section{7. "Vakiintuneeseen älä kajoa" ?1}

"Sanastotyön oppaan" mukaan vakiintuneita termejä ei koskaan pitäisi lähteä uusimaan kevyin perustein. Muutokset aiheuttavat aina viestintähäiriöitä, ja siksi tulisi arvioida perusteellisesti, onko tavoiteltu hyöty suurempi kuin muutostöistä aiheutuva haitta. Tarve uudistaa termistöä syntyy esimerkiksi silloin, kun käsitejärjestelmiin syntyy uusia tarkoitteita tai vanhoja poistuu. Esimerkiksi yhteiskunnalliset muutokset synnyttävät uusia instituutioita, jotka tarvitsevat uuden nimenkin. Muutostyöhön ryhtymiseen oikeuttaa myös termin kohteesta saatu uusi tieto, joka osoittaa vanhan termin epämielekkääksi (Haarala 1981: 32-33).

1 Varoitus on peräisin Matti Sadeniemeltä, joka toimi Kielitoimiston johtajana vuosina 1950-1974. Sadeniemen neuvo koski kuitenkin hyvän kielenkäytön normeja, ei niinkään kielioppitermejä. Ks. esim. Rintala 2000: 22. 
Verbien aikamuodot eivät ole uusia kategorioita, eikä muutoksen tarvetta siis voi perustella uudella tarkoitteella. Uutta tietoa aikamuotojen ominaisuuksista on sen sijaan kaikki saatu, mikä olisi syytä saada näkyväksi nimitystenkin tasolla. Mitä vakiintuneisuuteen tulee, huomauttaisin, että perinteisiin termeihin ovat tottuneet nimenomaan opettajat, joiden kasvatusalan ja kielen ammattilaisina olisi kyettävä kohtaamaan muutostöistä aiheutuvat paineet. Aloitteleville S2-opiskelijoillehan kaikki on uutta, myös termit.

Aivan lähimenneisyydestä löytyy rohkaisevia esimerkkejä vakiintuneistakin kielioppitermeistä, joiden käyttömukavuutta on onnistuttu huomattavasti parantamaan. Uudemmissa oppikirjoissa on alettu seurata "Ison suomen kieliopin" esimerkkiä, kun kömpelöt ja epäinformatiiviset 1. ja 3. infinitiivi on korvattu ergonomisemmilla nimityksillä A- ja MA-infinitiivi. Jopa persoonamuotoja ja astevaihtelua kuvaavaa termistöä on joissain teoksissa onnistuttu keventämään. Kirjassa "Suomen mestari 1" (Gehring \& Heinzmann 2011) minä-, sinä-, hän-, me-, te-, ja he-persoona ovat korvanneet vanhat ja kömpelöt nimitykset $y k s i$ kön ensimmäinen persoona jne. ja astevaihtelun sijaan puhutaan havainnollisemmin kpt-vaihtelusta. Nähtäväksi jää, ovatko tekijät saaneet parannuksia aikaan tempusten nimityksissä. "Suomen mestari" -sarjan 2. osa ilmestyy elokuussa 2012, ja 1. osassa aikamuodoista käsitellään vain preesensiä.

\section{Nimiehdotuksia}

"Sanastotyön oppaan" mukaan termiä luotaessa tulisi aluksi selvittää käsitteen paikka järjestelmässä sekä käsitteen sisältö. Uusi nimitys tulisi valita niin, että se välittää tietoa tarkoitteensa systemaattisista eli olennaispiirteistä, jotka ovat nimettävään tarkoitteeseen erottamattomasti kuuluvia ominaisuuksia. (Haarala 1981: 27-28.) Kehittelemäni termijärjestelmät, jotka seuraavaksi esittelen, on pyritty rakentamaan näiden periaatteiden mukaan. Olen pyrkinyt hyödyntämään mahdollisimman paljon jo olemassa olevia ratkaisuja. Mitä enemmän uudessa järjestel- 
mässä on tuttua, sitä helpommin se uskoakseni päätyy myös käyttöön. Kaikille seuraaville järjestelmille on yhteistä se, että nimitykset imperfekti, perfekti ja pluskvamperfekti on korvattu uudella kolmen termin sarjalla. Jokainen termi on rakenteeltaan yhdyssana tai sanaliitto, jonka edusosa tai pääsana ilmaisee kaikille kolmelle käsitteelle yhteisen olennaispiirteen eli sen, että kyseessä on kuluneen ajan tempus. Nimityksen määriteosaksi tai määritteeksi on valittu sana tai lyhenne, joka viittaa kunkin tempuksen omaan ja erityiseen olennaispiirteen.

On pidettävä mielessä, että on mahdotonta kehittää sellaista termistöä, joka palvelisi kaikkia S2-opiskelijoita yhtä hyvin. Akateemisella tasolla suomea opiskelevat tarvitsevat aivan erilaisen metakielen kuin turvapaikanhakijat tai ammatillisiin opintoihin pyrkivät nuoret maahanmuuttajat. Osa opiskelijoista voi hyödyntää englannin tai jonkin muun kielen taitoaan, mutta kaikilla ei ole tätä etua. Ergonomia on välineistön sovittamista työntekijälle sopivaksi. En katsonut siis järkeväksi kehittää yhtä termistöä yleisesti kaikille, vaan kolme erilaista järjestelmää erityyppisten ryhmien tarpeisiin. Termiehdotukseni on tarkoitettu kokeiltaviksi ja mieluusti myös edelleen kehitettäviksi.

\subsection{Preteritiin pohjautuva järjestelmä}

Imperfekti-nimitystä on jo pitkään ehdotettu korvattavaksi preterititermillä. Sen hyvänä puolena voi pitää neutraaliutta ja sisällön oikeellisuutta. Termi merkitsee yksinkertaisesti 'mennyttä aikaa', ja jättää avoimeksi verbin aspektin. Imperfektin korvaaminen preteritillä ei kuitenkaan riitä. Myös perfekti sen nykyisessä käytössä on virheellinen. Lisäksi imperfekti ja preteriti eivät edusta samaa hierarkiatasoa. Kielioppikomitea, joka v. 1906 asetettiin yhdenmukaistamaan kielenopetuksessa käytettävää terminologiaa, ei halunnut aikoinaan vaihtaa imperfekti-nimitystä preteritiksi. Perusteena käytettiin, että kyseinen verbimuoto ei ollut ainoa, jolla mennyttä aikaa ilmaistaan, eikä siis ainoa, josta preteriti-nimitystä voitaisiin käyttää (Mietintö 1915: 120). Tässä komitea oli oikeassa: latinan praeteritum on yläkäsite, joka esiin- 
tyy kaikkien menneen ajan tempusten nimissä niiden täydessä asussaan. Määritteet imperfectum, perfectum ja plusquamperfectum tarkentavat, millaisesta preteritistä puhutaan.

Ensimmäisessä järjestelmässäni olen palauttanut preteritin osaksi kaikkien menneen ajan tempusten nimityksiä. Termit perfekti ja imperfekti on kumpikin hylätty tai siirretty niille sopivampiin tehtäviin, ja yhdyssanamuotoisten termien määriteosiksi on otettu verbikategorioiden muodolliset tunnukset. Näin on saatu termit $i$-preteriti ja NUTpreteriti, haluttaessa tarkemmin NUT / TTU-preteriti. Malli tähän on saatu "Isosta suomen kieliopista" (ISK $₫ 120-122$ ), jossa infinitiivien ja partisiippien vanhat, numerointiin perustuvat nimitykset on korvattu läpinäkyvämmillä ja informatiivisemmilla tunnukseen perustuvilla nimityksillä. NUT-preteriti on tarkoituksellisesti samankaltainen kuin NUT-partisiippi, jotta uusi järjestelmä olisi yhteensopiva "Ison suomen kieliopin" kanssa. Tunnusainekset preteritin määriteosina ovat yksiselitteiset. Ne viittaavat olennaispiirteeseen, joka kyseisillä verbikategorioilla on aina. Lisäksi ne auttavat opiskelijaa palauttamaan mieleen, kuinka verbimuoto muodostetaan.

Koska pluskvamperfekti ilmaisee toimintaa, jonka tapahtumahetki on menneeseen aikaan sijoittuvaa viittaushetkeä varhaisempi, voidaan olettaa, että ainakin puhehetkestä käsin tarkastellen toiminta olisi loppuun saatettu ja ohi. Pluskvamperfekti lienee luonteeltaan perfektiivisempi kuin perfekti ja sen nimitys vähemmän virheellinen kuin muiden kuluneen ajan tempusten. Nimitys sisältää kuitenkin viittauksen perfektiin, jota järjestelmässä ei enää ole. Jotta saataisiin yhtenäinen kolmen termin systeemi, sekin olisi siis syytä uusia. Ehdottaisin pluskvamperfektin tilalle nimitystä kaksoispreteriti. Uusi määriteosa perustuisi siihen, että kyseinen liittomuoto sisältää molemmat preteritin tunnukset: apuverbissä $i$-preteritin ja pääverbissä NUT / TTU-preteritin tunnuksen. Lisäksi kyseisellä aikamuodolla viitataan tapahtumahetkeen, joka edeltää toista menneeseen aikaan sijoittuvaa ajankohtaa.

Preteritiin pohjautuva järjestelmä sopii sellaisille, jotka ovat tottuneet kielitieteen käsitteisiin. Uudet nimitykset avautuisivat helposti 
kielentutkijoille, opettajille sekä sellaisille S2-opiskelijoille, joiden äidinkielessä nimitystä käytetään tai jotka opiskelevat suomea akateemisella tasolla. Maahanmuuttajaryhmässä preteriti-pohjainen järjestelmä ei välttämättä olisi paras mahdollinen, kuten ei ehkä myöskään äidinkielen opetuksessa. Preteritiä ei ole juuri käytetty suomen kielen kuvauksissa 200 viime vuoden aikana, eli siitä lähtien kun Johann Strahlmann (1810: 84) otti käyttöön nykyisin tuntemamme järjestelmän. Äidinkielen kirjoihin preteriti ei ole löytänyt tietään lainkaan. Terminä se kuuluu lähinnä latinan kielen välineistöön, ja koska latinaa opiskellaan maassamme enää hyvin vähän, monet eivät ole koskaan kuulleet koko sanaa. Niin harhaanjohtavia kuin termit imperfekti ja perfekti ovatkin, sanoina ne ovat sentään useimmille tuttuja. Sisällöltään oikean preteritin heikkoudeksi voi osoittautua sen outous. Sinänsä oikeaoppinen termijärjestelmä voi jäädä vieraaksi käyttäjäkunnalleen, ja siksi sen rinnalla pitää olla vaihtoehtoja.

\subsection{Englanninkielinen järjestelmä}

Jos apukielenä voidaan tai halutaan käyttää englantia, uusi termistö rakentuu luontevasti termien past tai past tense pohjalle. Joissain englanninkielisissä S2-teoksissa käytetäänkin nimityksiä past tense (Karlsson 2002) tai simple past (White 2009) imperfektin tilalla. Termi simple past on yleinen myös englannin kielen kieliopeissa, ja sillä viitataan morfologiseen eli päätteen avulla muodostettuun menneen ajan tempukseen. Ranskan kieliopeissa on käytössä niin ikään morfologiseen menneen ajan tempukseen viittaava passé simple sekä myös liittomuotoon viittaava passé compose. Nämä jo käytössä olevat termit kantavat tietoa verbikategorian lajista (past) ja muodostustavasta (simple, composé), mutta eivät välitä erheellistä informaatiota aspektista. Muodostustapa on olennaispiirre, ja sitä voidaan hyödyntää määriteosana johdonmukaisesti. Nykyinen imperfekti korvataan nimityksellä simple past - kuten White jo tekeekin. Perfektin tilalla voidaan käyttää nimitystä composed past. Pluskvamperfektin tilalle ehdottaisin nimitystä double past sen kaksinkertaisten muodollisten tunnusten vuoksi. Vaihtoehtoisiksi tai 
rinnakkaisiksi nimiksi kävisivät myös tunnusainesta hyödyntävät $i$-past, NUT-past ja double past.

Täysin ongelmaton ei past-pohjainen termistö ole, sillä liittomuodoista NUT-preteriti - eli perinteisesti perfekti - ei aina ole menneen ajan muoto lainkaan. Se on luonteeltaan pikemminkin eräänlainen 'edellinen tai aikaisempi aika', previous tai before, kuin varsinainen past, 'mennyt'. Preesensin aputempuksena se voi olla merkitykseltään jopa futuurinen, jos se esiintyy tekstissä, jonka viittaushetki on tulevaisuudessa. Molemmat liittotempuksemme ovat itse asiassa luonteeltaan vertailevia: ne viittaavat ajankohtaan, joka on aikaisempi kuin jokin toinen hetki. Tämä eri aikatasoja suhteuttava piirre olisi hyvä saada osaksi liittotempusten nimityksiäkin. Itsestään selvänä se kuuluu niiden kuvauksiin ja määritelmiin.

\subsection{Omakielinen järjestelmä}

Omakieliset nimitykset aikamuodoille olisivat tarpeelliset sekä S2- että äidinkielenopetuksessa. Esimerkki onnistuneesta omakielisestä tempustermistöstä on viron järjestelmä (Erelt ym. 2000: 214-215; Annekatrin Kaivapalun kommentti AFinLA:n esitelmätilaisuudessa (Kok 2011). Viron tempusnimitysten kanssa näyttää olleen aikaisemmin samanlaisia ongelmia kuin meilläkin:

(16) Eesti verbi ajavormid on kõigepealt lihtvormid preesens (tuleb, kirjutab) ja imperfekt - mis sisuliselt on preteeritum - (tuli, kirjutas). (Metslang 1993: 203.)

Ongelmiin on kuitenkin tartuttu, ja uudessa omakielisessä järjestelmässä preesensistä käytetään nimitystä olevik ja $i$-preteritistä lihtminevik eli 'yksinkertainen mennyt aika' (vrt. simple past). NUT / TTU-preteritin vastine täisminevik ('täysmennyt') hieman arveluttaa, sillä se näyttäisi sisältävän viittauksen toiminnan perfektiivisyyteen eli päättyneisyyteen. Termi saattaa sopia kuvaamaan viron tilannetta, mutta suomen perfektiksi kutsutulle verbimuodolle ei tulisi antaa nimitystä täysmen- 
nyt aika, koska sen ilmaisema tapahtuma voi vielä puhehetkellä jatkua. Perinteisen pluskvamperfektin vastineena käytettävä enneminevik on sen sijaan osuva, sillä se viittaa tempuksen kahta ajankohtaa vertailevaan luonteeseen.

Vironkieliset termit ovat paitsi sisällöllisesti onnistuneita myös nasevia. Niiden suora suomentaminen tuottaa kuitenkin sellaisia sanahirviöitä kuin yksinkertainen mennyt aika tai mennyttä edellinen aika I aikaisemmin mennyt aika. Tällaiset pitkät ja raskaat käsitteet sopivat kyllä osaksi aikamuotojen kuvauksia ja määritelmiä. Varsinaisten termien pitäisi kuitenkin olla lyhyitä ja hyvin mieleen jääviä. Suomenkielisiksi nimityksiksi ehdottaisin siksi termejä i-mennyt, NUT-mennyt ja kaksoismennyt (aika). Lisäksi jos halutaan huomioida, ettei NUT-mennyt ole niinkään mennyt kuin edellinen tai aikaisempi aika, voisi sellainen aikamuotojen sarja kuin mennyt aika, edellisaika ja mennyt edellisaika I menneen edellisaika olla ainakin sisällöllisesti oikein.

\subsection{Yksittäisiä tilapäis- ja apukäsitteitä}

I-preteritin tyypillinen esiintymisympäristö on kertova teksti, ja tätä tietoa olen toisinaan hyödyntänyt sellaisissa tilapäistermissä kuin narratiivi tai tarina-aika, englanniksi narrative tense tai story time. Vastaavia nimityksiä käyttää myös White:

(17) Sometimes the time shows in the context, which is why the imperfect is sometimes called the story-telling tense, or the narrative tense form. (White 2008: 199.)

Omille opetusryhmilleni näistä aputermeistä on ollut hyötyä, sillä ne kantavat tietoa $i$-preteritin diskursiivisesta käytöstä ja esiintymisympäristöstä. Narratiivi jää myös paremmin opiskelijoiden mieleen kuin kankea $i$-preteriti. Liittomuodoille on kuitenkin ollut vaikea keksiä vastaavanlaisia nimityksiä. Niille on hankala osoittaa samanlaista tyypillistä käyttöympäristöä kuin $i$-preteritille, sillä niitä käytetään paljon toisten tempusten apuna, NUT-preteritiä preesensin ja kaksoispreteritiä $i$-preteritin rinnalla. Kaksoispreteriti on itsenäisesti käytettynä harvinainen. 
NUT-preteritiä käytetään joskus itsenäisestikin, ja kokonaan sille rakentuva teksti on usein luonteeltaan tapahtumien tai tehtyjen töiden lista. Olisiko listatempus tai catalogue time sille sitten hyvä nimi? En suosittelisi kumpaakaan vaihtoehtoa kuin korkeintaan tilapäisiksi tarkoitetuissa luonnehdinnoissa. NUT-preteritin luettelomaisuus on kuitenkin opiskelijalle relevanttia tietoa. Esimerkiksi työhaastattelussa opiskelijoiden on hyvä osata kertoa asioista ja tehtävistä, joita he ovat joskus tehneet. Haastattelutilanteeseen valmistuminen on luonteva konteksti harjoitella NUT-preteritin käyttöä.

Tilapäisnimityksistä hyötyvät opiskelijat, jotka eivät ole tottuneet kieliopillisiin termeihin tai koulumaiseen opiskeluun. Niitä voi luoda tarpeen mukaan, ja joskus opiskelijoillakin on hyviä ehdotuksia, joita kannattaa hyödyntää. Nimityksistä voi myös neuvotella. Erään ryhmän kanssa päädyimme käyttämään $i$-preteritistä väliaikaisesti nimitystä vanha aika. Se oli ryhmän mielestä helpompi hahmottaa kuin i-mennyt. Tilapäisnimityksien kanssa tulee kuitenkin olla huolellinen. Koska ne syntyvät tietyssä käyttökontekstissa ja hetken tarpeisiin, ne eivät aina perustu nimettävän käsitteen olennaispiirteelle. Tyypillinen tilapäisnimitys viittaa piirteeseen, joka sen tarkoitteella on toisinaan tai jopa usein mutta ei aina. Kertomus ei ole ainoa konteksti, jossa $i$-preteriti voi esiintyä. NUT-preteritiä käytetään muuhunkin kuin listojen laatimiseen. Samoin sellainen havainnollistava tilapäistermi kuin "verbin eilenmuoto" (Tukia ym. 2004: 84-85) voi olla erittäin hyödyllinen tietyssä tilanteessa. Se voi kuitenkin johtaa myös harhaan, jos eilen-määrite käsitetään kirjaimellisesti. Opettajan on huolehdittava, että näin ei pääse käymään.

\section{Lopuksi}

Opetuksen metakielen perustaksi tarvitaan edelleen nimitysjärjestelmiä, jotka systemaattisella tavalla välittävät tietoa tarkoitteistaan. Hyvätkään tilapäisnimitykset eivät voi varsinaisia termejä täysin korvata. Määrätietoinen työskenteleminen tempustermistön eteen olisi hyvä 
investointi koko kognitiivisen työvälineistömme ergonomiaan. Jos siinä onnistuttaisiin, vaivan palkka olisi suuri. Osuvat nimitykset auttaisivat opiskelijoita ymmärtämään paremmin aikamuotojen ominaisluonnetta. Opettajien ei tarvitsisi enää käyttää aikaa huonojen termien selittelemiseen, puolustelemiseen ja vaarattomaksi tekemiseen, ja näin säästyvän ajan voisi käyttää johonkin hyödylliseen tai jopa hauskaan. Myös aspekti-ilmiön kuvaamiseen saataisiin välineistöä, kun termit imperfekti ja perfekti vapautuisivat siihen käyttöön, jota varten ne alun perin luotiinkin. Muutosta tuskin saadaan aikaan ilman vastustusta, ja uudet nimitykset kannattaakin ehkä aluksi ottaa käyttöön rinnakkaistermeinä. Jos ne ovat tarpeeksi onnistuneita, puhuvat ne silloin itse puolestaan. Näin vanhoista termeistä päästään ehkä eroon ilman, että niitä vastaan tarvitsee erityisesti käydä taistelemaan.

\section{Lähteet}

Erelt, Mati, Tiiu Erelt, Kristiina Ross 2000. Eesti keele käsiraamat. Tallinn: Eesti Keele Sihtasutus.

Gehring, Sonja, Sanni Heinzmann 2011. Suomen mestari 1. Suomen kielen oppikirja aikuisille. Helsinki: Finn Lectura.

Haarala, Risto 1981. Sanastotyön opas. Helsinki: Kotimaisten kielten tutkimuskeskus.

ISK = Auli Hakulinen, Maria Vilkuna, Riitta Korhonen, Vesa Koivisto, Tarja-Riitta Heinonen, Irja Alho 2004. Iso suomen kielioppi. Suomalaisen Kirjallisuuden Seuran toimituksia 950. Helsinki: Suomalaisen Kirjallisuuden Seura.

Itkonen, Erkki 1966. Kieli ja sen tutkimus. Helsinki: WSOY.

Kangasmaa-Minn, Eeva 1993. Aspektista ja sen sukulaisilmiöistä suomalaisugrialisissa kielissä. - Valma Yli-Vakkuri (Toim.). Studia comparativa linguarum orbis Maris Baltici 1. Tutkimuksia syntaksin ja pragmasyntaksin alalta. Turun yliopiston suomalaisen ja yleisen kielitieteen laitoksen julkaisuja 43. Turku: Turun yliopisto, 13-23.

Kok, Maria 2011. Verbien aikamuodot S2-opetuksessa. - Esitelmä AFinLA:n syyssymposiumissa Joensuussa 11.-12.11.2011.

Korhonen, Riitta 2011. Oi aikoja, oi tempuksia! Muutamia kysymyksiä aikamuodoista. - Kielikello 3, 4-7. 
Lyytikäinen, Erkki 1997. Aikataulukon arvoitus: suomen tempussysteemin perusteita. - Kielikello 1, 8-12.

Martinius, Matthias 1689. Hodegus Finnicus eller Finsk Wägwijsare. Holmiae: Joh. Georg Eberdt. Näköispainos 1968. Vanhat kielioppimme. Petraeus 1649. Martinius 1689. Vhael 1733. Helsinki: Suomalaisen kirjallisuuden seura.

Metslang, Helle 1993. Verbitarind ajatähendust väljendamas. - Virittäjä 97 (2), 203-221.

Mietintö 1915 = Vuonna 1906 helmikuun 13 päivänä yhtenäisyyden ja yhdenmukaisuuden aikaansaamiseksi kieliopin opetuksessa asetettu komitea: Kieliopillinen luonnos. Ehdotus yhteisiksi termeiksi ja määritelmiksi. Helsinki: Keisarin senaatin kirjapaino.

Petraeus, Eskil 1649. Linguae Finnicae Brevis institutio. Åbo: Petrus Wald. Näköispainos 1968. Vanhat kielioppimme. Petraeus 1649. Martinius 1689. Vhael 1733. Helsinki: Suomalaisen kirjallisuuden seura.

Rikstermbanken. http://www.rikstermbanken.se (21.5.2012).

Rintala, Päivi 2000. Oikeakielisyydestä kielenhuoltoon. - Kielikello 1, 19-23.

Siitonen, Kir sti 1999. Agenttia etsimässä. U-verbijohdokset edistyneen suomenoppijan ongelmana. Turun yliopiston suomalaisen ja yleisen kielitieteen laitoksen julkaisuja 63. Turku: Turun yliopisto.

Siitonen, Kirsti 2000. Kieliopin terminologia tuottamassa ongelmia suomi toisena kielenä -opetuksessa. - Pirkko Muikku-Werner, Hannu Remes (Toim.). VIRSU - viro ja suomi: kohdekielet kontrastissa. Lähivertailuja 13. Joensuu: Joensuun yliopisto, 81-87.

SK-TSK = Sanastokeskus TSK ry. http://www.tsk.fi/tsk/ (21.5.2012).

Strahlmann, Johann 1810. Finnische Sprachenlehre für Finnen und Nicht-Finnen. St. Petersburg: M.E. Ibersen. - Kalevi Wiik (Toim.). Suomen wanhat kieliopit. Nide 1: 1649-1816. Turku: Turun yliopiston fonetiikan laitos, 1987.

TKTP $=$ Tieteen kansallinen termipankki. Helsingin yliopiston suomen kielen, suomalais-ugrilaisten ja pohjoismaisten kielten ja kirjallisuuksien laitos. http://tieteentermipankki.fi/wiki/Termipankki:Etusivu (21.5.2012).

Tommola, Hannu 1993. Ambipersoonainen suppressiivi: diateesista suomessa ja virossa. - Valma Yli-Vakkuri (Toim.). Studia comparativa linguarum orbis Maris Baltici 1. Tutkimuksia syntaksin ja pragmasyntaksin alalta. Turun yliopiston suomalaisen ja yleisen kielitieteen laitoksen julkaisuja 43. Turku: Turun yliopisto, 41-96.

$\mathrm{TTL}=$ Työterveyslaitos. http://www.ttl.fi/fi/ergonomia/mita ergonomia on/ Sivut/default.aspx (21.5.2012). 
TSK 36 = Terminologian sanasto. Sanastokeskus TSK ry, Helsinki 2006. Saatavissa PDF-muodossa osoitteesta http://www.tsk.fi/tiedostot/pdf/TerminologianSanasto.pdf (21.5.2012).

Vihonen, Sakari 1978. Suomen kielen oppikirja 1600-luvulla. Kieliopillinen ajattelu 1600-luvun suomen kielen oppikirjoissa. Studia Philologica Jyväskyläensia 11. Jyväskylä: Jyväskylän yliopisto.

Wiik, Kalevi 1976. Suomen tempusten syvä- ja etärakenteista. - Virittäjä 80, 135162.

Vhael, Bartholdus 1733. Grammatica Fennica. Åbo: Johan Kiämpe. Näköispainos 1968. Vanhat kielioppimme. Petraeus 1649. Martinius 1689. Vhael 1733. Helsinki: Suomalaisen Kirjallisuuden Seura.

\section{Aineistolähteet}

Hart, Susanna 2007. Suomea paremmin. Helsinki: Finn Lectura.

Kangasniemi, Heikki 2007a. Suomen kielen tikapuut. Kielioppi- ja harjoituskirja, alkeistaso 1. Tampere: Tampereen yliopistopaino.

Kangasniemi, Heikki 2007b. Suomen kielen tikapuut. Kielioppi- ja harjoituskirja, alkeistaso 2. Tampere: Tampereen yliopistopaino.

Karanko, Marjatta, Ulla Paavilainen 2006. Tottakai! Suomen kielen alkeisoppikirja. Helsinki: Finn Lectura.

Karlsson, Fred 2002. Finnish - An Essential Grammar. London: Routledge.

Kenttälä, Marjukka 2006. Suomi sujuvaksi 1. Helsinki: Gaudeamus.

Kuparinen, Kristiina, Terhi Tapaninen 2008: Hyvin menee! 2. Suomea aikuisille. Helsinki: Otava.

Lepäsmaa, Anna-Liisa, Leena Silferberg 1998. Suomen kielen alkeisoppikirja. Helsinki: Finn Lectura.

Tukia, Kaisa, Eija Aalto, Peppi Taalas, Sanna Mustonen 2004. Suomi 2 - Minä ja arki. Helsinki: Otava.

White, Leila 2008. A Grammar Book of Finnish. Helsinki: Finn Lectura.

White, Leila 2009. From Start to Finnish - A Short Course in Finnish. 8. painos. Finn Lectura: Helsinki.

\section{Maria Kok}

Itä-Suomen yliopisto, Joensuun kampus

Yliopistokatu 2, PL 111

80101 Joensuu, Finland

maria.kok@uef.fi 


\title{
Grammatical terminology as a tool: On the tense system and the ergonomics of its teaching practices in L2-Finnish
}

\author{
MARIA KOK \\ University of Eastern Finland
}

The metalanguage used to describe grammatical categories can be addressed as a set of professional and cognitive tools that are used by the teacher and student together. Their purpose is to facilitate the learning process, and their efficiency can be evaluated from an ergonomic point of view. Ergonomics is a professionally oriented field of research and practice. Though most professions have ergonomic applications of their own, for grammar or language education such practice has not yet been developed. If created, grammatical ergonomics could be an application of cognitive ergonomics which deals with representation of information, learning processes and the limitations of human memory. Also concept analysis and vocabulary studies could provide resources for grammatical ergonomics, for the cognitive tools used in language education consists for a good deal of terminology, definitions, explanations and examples.

Ergonomic evaluation is attempted on a set of grammatical terms that are known to be problematic. The traditional Latin based names given to the Finnish verbal past tenses do not correctly describe the grammatical categories they are referring to. Little has been done to correct the situation even the need for better terminology increases day by day as does the number of people studying Finnish.

Especially confusing are the tenses named imperfekti and perfekti. The first refers to a morphological past tense commonly used in narrative texts. The latter is used about a composed past tense referring to events that have been started in the past, may still be going on at the present moment and even if completed have some relevance at the moment of utterance. The names given to these tenses suggest an aspectual opposition between them. This is highly misleading, for when there is any difference in aspect, it is the imperfekti that has a strong tendency towards a perfective aspect while the perfekti often expresses an imperfective 
aspect. In many cases changing the tense does however not change the aspect. In Finnish, the final aspectual meaning of a verbal expression depends on several factors working together. The tense is just one of them. Others are the choice between the partitive and total object, the great variety of verbs derivates to choose from and even the basic meaning of the root verb. The terms perfekti and imperfekti could be useful tools for studying the aspect but as long as they are used as tense names, this is not possible.

In order to study the tenses efficiently, the teacher and the student need a set of cognitive tools, and an adequate name system for the past tenses should be created without delay. In this article, three suggestions for a new set of terms are given. The first set, mainly for traditional grammar and academic use, is based on the Latin term praeteritum. The second should be suitable for study groups using English as a metalanguage. For groups studying in Finnish altogether, a third set is created, and this one may also benefit Finnish L1-students. Because the traditional names of the tenses have been firmly established throughout the Finnish educational system, new names are likely to meet resistance first. It is therefore suggested that the new set of names will be used as parallel or alternative terms first. They are more likely to be accepted, if their users have had the chance to test them and to develop them further.

Keywords: grammatical terminology; tense; aspect; cognitive ergonomics; Finnish as a second language 